
A
$\mathbf{R}$
$\mathbf{T}$
$\mathbf{Y}$
$\mathbf{K}$
$\mathbf{U}$

\title{
Grunty strukturalne w Polsce
}

\author{
Patterned grounds in Poland
}

\begin{abstract}
MACIEJ DĄBSKI
Wydział Geografii i Studiów Regionalnych, Uniwersytet Warszawski, 00-927 Warszawa; Krakowskie Przedmieście 30; mfdbski@uw.edu.pl
\end{abstract}

Zarys treści. Artykuł dotyczy gruntów strukturalnych występujących w Polsce, z podziałem na tereny objęte zlodowaceniem skandynawskim i górskie. Grunty strukturalne występujące poza górami mają charakter kopalnych poligonów niesortowanych dużej skali i można je zaobserwować jedynie na zdjęciach lotniczych wykonanych przy sprzyjających warunkach - pogodowych poprzedzających nalot i litologicznych - oraz przy odpowiednim użytkowaniu gruntu. Są one zapisem funkcjonowania wieloletniej zmarzliny w okresie ostatniego zlodowacenia plejstoceńskiego. W wysokogórskiej strefie peryglacjalnej polskich Karpat i Sudetów występują aktywne grunty strukturalne w postaci sortowanych sieci małej skali i tufurów. Sortowane poligony, sieci i pasy dużej skali są zazwyczaj reliktowe, a ich główny okres rozwoju przypadał na schyłek plejstocenu.

Słowa kluczowe: grunty strukturalne, Polska, zdjęcia lotnicze, strefa peryglacjalna.

\section{Wstęp}

Grunty strukturalne (ang. patterned ground, niem. Strukturboden) widoczne są na powierzchni terenu jako względnie uporządkowany, regularnie powtarzający się wzór, spowodowany charakterystycznym rozmieszczeniem: (1) roślinności bądź niewielkich nierówności powierzchni terenu lub (2) różnych frakcji, zwykle kamieni lub żwiru względem frakcji ziemistych (Washburn, 1973; van Everdingen, 1998). Zależnie od tego, który czynnik odpowiada za wspomniany wzór (1 lub 2) grunty strukturalne dzieli się na niesortowane i sortowane. Struktury te mogą być małej skali (średnica „oczek w sieci” rzędu 0,1-1,5 m) lub dużej skali (zwykle od kilku do kilkudziesięciu metrów). Ze względu na kształt podstawowych komórek lub „oczek w sieci” wyróżnia się z kolei: poligony, pierścienie, sieci (struktury pośrednie między pierścieniem a poligonem), labirynty, stopnie (girlandy, terasetki) oraz pasy (Washburn, 1956, 1970, 1973, 1979; Kessler i Werner, 2003). Mechanizmy powstawania gruntów strukturalnych są różnorodne, jednak najczęściej przyczyną są procesy pęcznienia i osiadania mro- 
zowego, sortowania mrozowego, kontrakcji termicznej i soliflukcji (vide Dąbski, 2006). Obecność wieloletniej zmarzliny sprzyja, a czasem jest konieczna do rozwoju pewnych typów gruntów strukturalnych. Struktury te są charakterystyczne dla strefy peryglacjalnej związanej z wysokimi szerokościami geograficznymi oraz piętrami alpejskim i subniwalnym, stanowią zatem wyznacznik pewnych warunków klimatycznych, które (w zależności od tego, czy mamy do czynienia z aktywnymi, reliktowymi czy kopalnymi strukturami) panują lub panowały na danym terenie (Jahn 1970a; Embleton i King, 1975; Ballantyne i Harris, 1994; French, 1996).

Celem artykułu jest przedstawienie dotychczasowego stanu wiedzy na temat gruntów strukturalnych współcześnie widocznych na powierzchni ziemi w Polsce. W celu pełniejszego ujęcia zagadnienia autor przytacza również przykłady gruntów strukturalnych leżących poza terytorium kraju. Kopalne grunty strukturalne występują głównie w pasie nizin, natomiast formy reliktowe - ponad górną granicą lasu w Karpatach i Sudetach (grunty struktury dużej skali), dokumentując plejstoceńską wieloletnią zmarzlinę i surowsze warunki klimatyczne. Aktywne grunty strukturalne (głównie tufury i sieci sortowane małej skali) są zapisem współcześnie zachodzących procesów mrozowych ponad górną granicą lasu.

\section{Kopalne grunty strukturalne poza obszarami górskimi}

Zdjęcia lotnicze wykonane przy sprzyjających warunkach wilgotnościowych gleby umożliwiają niekiedy zaobserwowanie odwzorowania kopalnych poligonów mrozowych na powierzchni ziemi dzięki różnicy w uwilgotnieniu materiału wypełniającego kliny i materiału, w którym wykształciły się poligony. Różnice te bywają podkreślone przez roślinność (znaczniki roślinne, np. jęczmień i owies), która lepiej zakorzenia się w wilgotniejszym i drobnoziarnistym osadzie wypełniającym kliny (Christensen, 1974) lub szybciej dojrzewa w suchszych piaszczystych wypełnieniach szczelin wytworzonych w glinie zwałowej (Bogdański i Kijowski, 1990). Poligony mają różne wymiary, od kilku do kilkudziesięciu metrów, przy czym średnica poligonów zależy od materiału, w którym się wykształciły - mniejsze poligony (od kilku do kilkunastu metrów średnicy) są w glinie zwałowej (lub innych osadach kohezyjnych), większe w piaszczystożwirowych osadach sandrowych lub rzecznych (Jahn, 1970a; Goździk, 1973; French, 1996). Wiek opisywanych poligonów mrozowych określa się na ostatnie zlodowacenie (Williams, 1964), jego kulminację (Christensen, 1974; Walters, 1978, 1994) lub schyłek (Morgan, 1971; Maizels, 1986; Johnson, 1990; Walters, 1994), choć w niektórych przypadkach nie wyklucza się wieku starszego, odpowiadającego zlodowaceniu Warty (Williams, 1964).

Historia zastosowania fotografii lotniczej do rejestracji kopalnych poligonów mrozowych przedstawiona została w pracy M. Dąbskiego i innych (2008). Tech- 
nikę tę stosuje się od lat m.in. w Wielkiej Brytanii (Shotton, 1960; Williams, 1964; Morgan, 1971; Maizels, 1986), w Danii i Szwecji (Svensson, 1964; Christensen, 1974; Maizels, 1986) oraz w Stanach Zjednoczonych (Walters, 1978, 1994; Johnson, 1990). Identyfikacji i skartowaniu kopalnych poligonów mrozowych na zdjęciach lotniczych sprzyjają następujące elementy: minimum dwutygodniowy okres o niskich opadach atmosferycznych poprzedzający wykonanie zdjęć, istotna różnica uziarnienia osadu wypełniającego kliny i osadu, w którym szczeliny się wykształciły (np. piaski eoliczne w glinie zwałowej), względnie młody wiek szczelin mrozowych (ostatnie zlodowacenie) i ich płytkie występowanie (tuż pod glebą) oraz dojrzewająca uprawa jęczmienia, owsa czy lucerny (Svensson, 1982).

W Polsce po raz pierwszy poligony mrozowe zidentyfikował na czarno-białych zdjęciach lotniczych w skali 1:10 000 z okolic Zduńskiej Woli H. Gawlik (1970). Po wykonaniu szurfu okazało się, że w warciańskiej glinie zwałowej wykształcone zostały szczeliny mrozowe z pierwotnym wypełnieniem piaszczystym, a ich górne partie szerokie na 10-25 cm występują na głębokości około $60 \mathrm{~cm}$ pod powierzchnią ziemi.

Kolejne badania przeprowadzili P. Bogdański i A. Kijowski (1990) w pobliżu Sulejewa i Grabianowa (okolice Poznania). Na pionowych zdjęciach lotniczych w skali 1:5000 i 1:10 000 przedstawiających pola zajęte pod uprawy lucerny i jęczmienia uwidoczniły się sieci poligonów należących do dwóch generacji spękań: pierwsza dająca poligony o średniej długości boków 15,2 m i druga $4 \mathrm{~m}$. Sfotografowane poligony powstały w glinie zwałowej fazy leszczyńskiej stadiału głównego ostatniego zlodowacenia. W wykopach stwierdzono, że około $60 \mathrm{~cm}$ pod powierzchnią ziemi uwidoczniają się szerokie na blisko $70 \mathrm{~cm}$ górne części klinów mrozowych z drobnym piaskiem, stanowiącym ich pierwotne wypełnienie. Badania te rozwinął S. Kozarski (1993, 1995), który poligony mrozowe udokumentował na zdjęciach lotniczych w skalach 1:1000, 1:2500, 1:5000 wykonanych w Wielkopolsce na obszarze między maksymalnym zasięgiem ostatniego zlodowacenia a jego fazą poznańską. Długości boków poligonów były różne w zależności od generacji spękań i wynosiły od 3,3 do 17,2 m. Sfotografowane poligony przedstawiają spękania $\mathrm{w}$ bazalnej glinie polodowcowej wypełnione piaskiem eolicznym. Górne części klinów mają szerokość do $80 \mathrm{~cm}$ i można się na nie natknąć około $50 \mathrm{~cm}$ pod powierzchnią ziemi, nieco niżej kliny zwężają się do około $20 \mathrm{~cm}$. Nad nimi zalega piaszczysta pokrywa ablacyjna, a niekiedy warstwa gliny zwałowej, która zamknęła się nad klinem w obrębie warstwy czynnej (Kozarski, 1995). Na niektórych fotografiach widoczne były poligony wykształcone w osadach fluwioglacjalnych i wówczas ich przeciętna średnica była większa - wynosiła około 20-30 m (Kozarski, 1995).

Wiek opisywanych przez P. Bogdańskiego i A. Kijowskiego (1990) oraz przez S. Kozarskiego $(1993,1995)$ poligonów mrozowych szacuje się na schyłek ostat- 
niego zlodowacenia (od około 20 tys. lat BP aż do starszego dryasu), kiedy ustępujący lądolód umożliwiał rozwój wieloletniej zmarzliny.

Poligony mrozowe są niekiedy rejestrowane na zdjęciach lotniczych wykonanych do badań archeologicznych, stanowiąc tło geologiczne (Champion, 1980; Kijowski i Żynda, 2005). Dzięki życzliwości archeologów: prof. W. Rączkowskiego oraz dr. D. Krasodębskiego autor artykułu dysponuje zdjęciami lotniczymi wykonanymi w okolicach Leszna, Poznania i Kruszwicy (obszar młodoglacjalny) oraz w okolicy Bielska Podlaskiego (obszar staroglacjalny) (fot. 1, 2). Widać na nich wyraźnie zespoły poligonów pochodzenia prawdopodobnie peryglacjalnego.

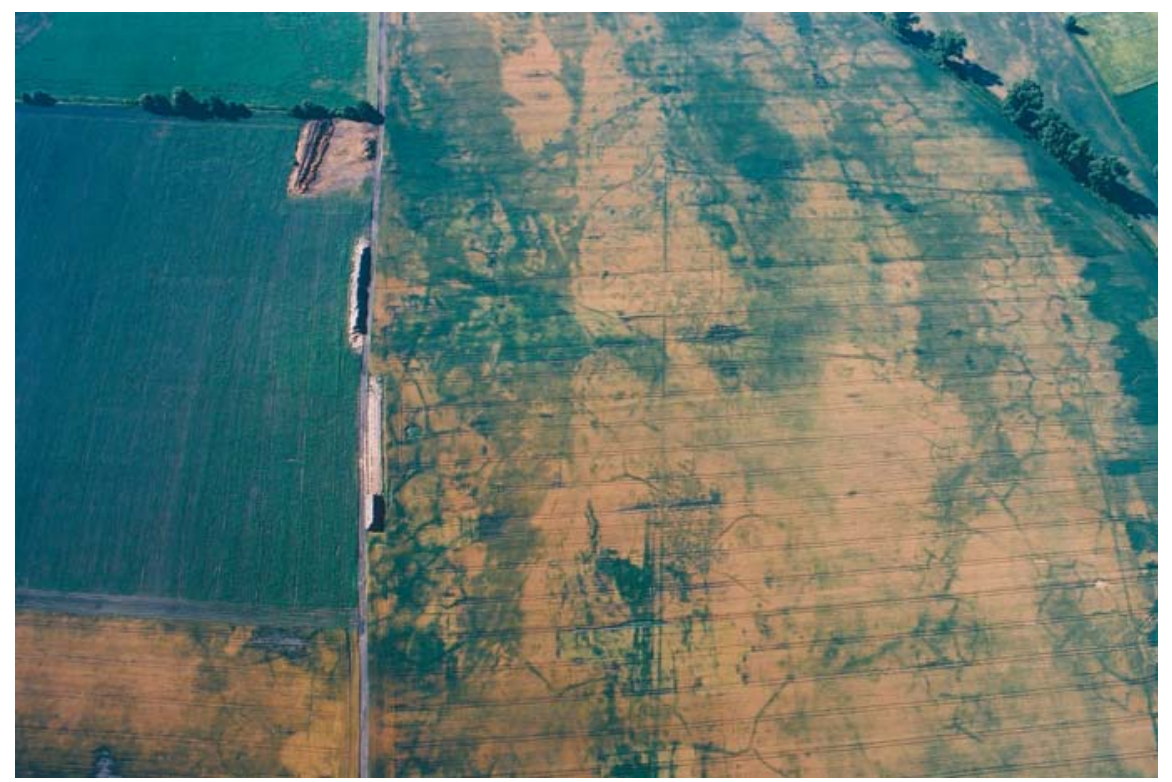

Fot. 1. Kopalne niesortowane poligony mrozowe dużej skali widoczne na powierzchni pola zajętego pod uprawę zbóż w okolicy Kruszwicy

Fossil large-scale non-sorted frost polygons visible in a field of cereals near Kruszwica (fot./photo by W. Raczkowski)

W wyniku dotychczas przeprowadzonych prac udało się potwierdzić peryglacjalne pochodzenie poligonów w miejscowościach Wielki Sławsk i Chełmiczki koło Kruszwicy (Dąbski i inni, 2007). W obu miejscowościach kliny mrozowe wykształciły się w glinie zwałowej i wypełnione są piaskiem o genezie eolicznej. Trwają prace nad poligonami widocznymi na zdjęciach w rejonie Otorowa koło Szamotuł (Tokaj, 2011), na obszarze przykrytym osadami piaszczystymi. 
Częściowo poligonalny przebieg mają także suche dolinki w okolicach wsi Rogatka koło Dubienki (Dąbski i Szwajgier; 2005). W dolinie Bugu, na terasie plejstoceńskiej wieku warciańskiego, wykształcił się system płytkich suchych dolinek, które swoim przebiegiem przypominają poligony mrozowe. Głębokość dolinek wynosi średnio od około 2 do 4 m, szerokość 10-20 m (ryc. 1). Dolinki te są zwykle wypełnione torfem o miąższości około $1 \mathrm{~m}$ i porośnięte lasem olesowym lub zakrzaczone. Poniżej torfu występują sine piaski z poziomymi przewarstwieniami mułków. M. Dąbski i W. Szwajgier (2005) postawili hipotezę, że są to formy termokrasowe rozwinięte na dawnych klinach lodowych. Podobne wytłumaczenie genezy płytkich suchych dolinek wykształconych na Równi-

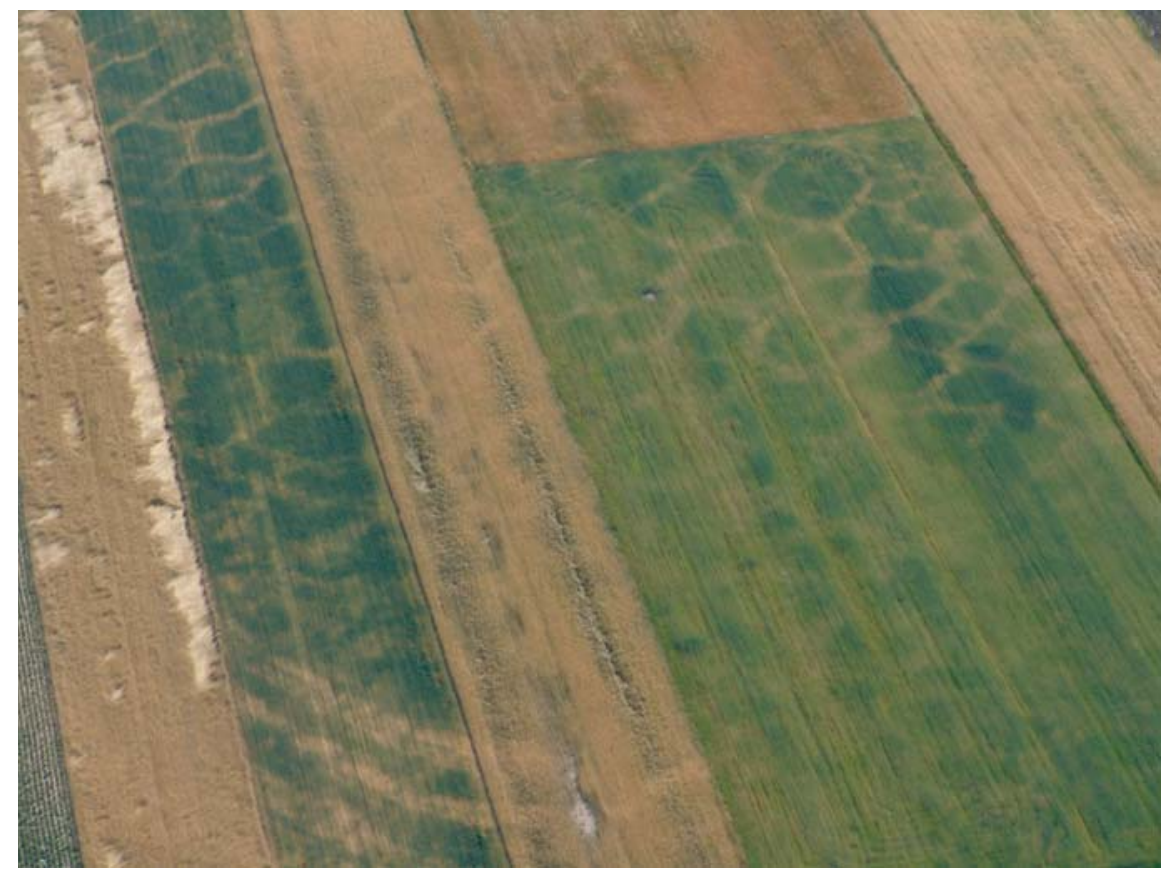

Fot. 2. Poligonalne wzory widoczne na zdjęciu lotniczym w okolicy Bielska Podlaskiego Polygonal patterns visible of an aerial photograph taken near Bielsk Podlaski (fot./photo by D. Krasnodębski)

nie Laholm w południowo-zachodniej Szwecji przyjmują H. Svensson (1982) i J. Maizels (1986) oraz A.I. Popov (1962) - do wyjaśnienia rozwoju rzeźby blokowej na Syberii. 

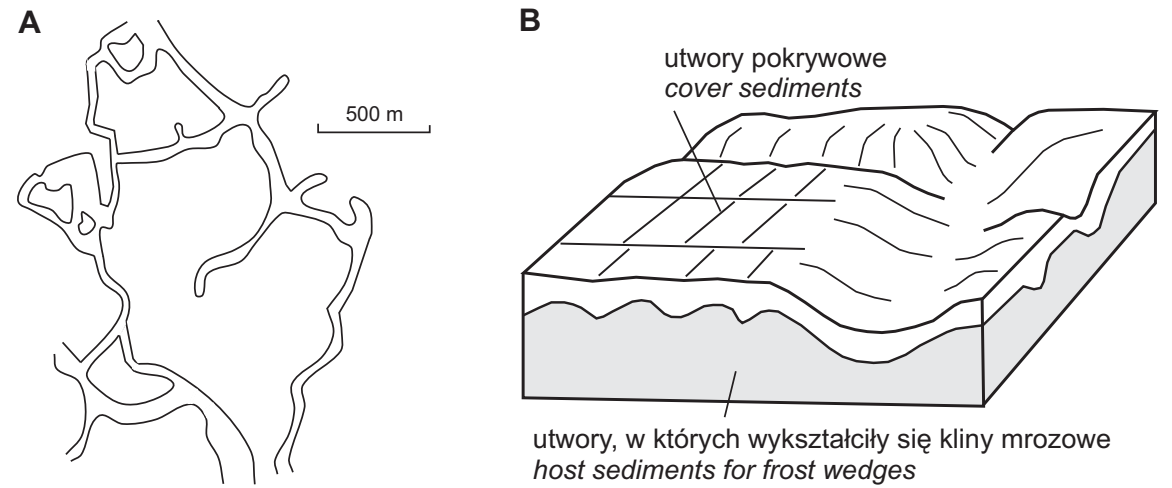

Ryc. 1. A - quasi-poligonalny układ suchych dolinek w okolicy Rogatki; opracowanie własne na podstawie: Dąbski i Szwajgier (2005); B - schemat rzeźby blokowej; opracowanie własne na podstawie: Popov (1962)

A - a quasi-polygonal pattern of dry valleys near Rogatka; author's elaboration based on: Dąbski and Szwajgier (2005); B - scheme of blocky relief; author's elaboration based on: Popov (1962)

\section{Grunty strukturalne w górach}

Piętro peryglacjalne w polskich górach występuje przede wszystkim w Tatrach i w Karkonoszach, a grunty strukturalne wykształcone w tych regionach doczekały się już wielu opracowań (Walczak, 1948; Jahn, 1950, 1951, 1958, 1963, 1970b; Pulina, 1968; Pulinowa i Pulina, 1972; Traczyk, 1992; Sekyra i Sekyra, 1995; Rączkowska, 2007). Większą liczbę prac poświęcono gruntom strukturalnym rozwiniętych po stronie słowackiej i czeskiej (Walczak, 1948; Kunský i Zaruba, 1950; Sekyra, 1950, 1954, 1956; Andusov, 1954; Ksandr, 1954; Kunský i Louček, 1956; Jahn, 1958; Zatko, 1961; Lukniš, 1973; Pelíšek, 1974; Sekyra i Sekyra 1995; Rączkowska, 2002, 2007; Kř́ižek i inni, 2007; Treml i inni, 2010).

Zestawienie informacji na temat rozmieszczenia stanowisk gruntów strukturalnych w Tatrach Wysokich, w masywie Czerwonych Wierchów oraz w Tatrach Bielskich, przedstawił na mapie L. Kasandr (1954). Niedawno Z. Rączkowska (2007) opublikowała mapę i tabelaryczne zestawienie stanowisk form peryglacjalnych (w tym gruntów strukturalnych) w całych Tatrach. Zdecydowana większość stanowisk znajduje się po stronie słowackiej, w tym jedno z najlepiej opisanych stanowisk aktywnych pierścieni i poligonów sortowanych przy Hińczowym Oku (Rączkowska, 2002, 2007) oraz znaczny obszar z wyraźnymi reliktowymi sortowanymi gruntami strukturalnymi dużej skali na przełęczy Lučne sedlo (Ksandr, 1954; Jahn, 1958; Lukniš, 1973). 
Tatrzańskie piętro peryglacjalne, w którym współcześnie najintensywniej zachodzą procesy pęcznienia mrozowego, uwarunkowane: reżimem termicznym, dużym uwilgotnieniem gruntu, grubością warstwy zwietrzeliny oraz skąpą roślinnością, obejmuje piętra subalpejskie i alpejskie, między 1500 a 2200 m npm. (Widacki, 1975; Gerlach, 1970; Kotarba, Starkel, 1972; Rączkowska 2007). Najniżej występującymi aktywnymi gruntami strukturalnymi są pagórki tufurów występujące na stokach: Kominów Tylkowych od 1500 m npm., Małej Koszystej od 1600 m npm., Kobylarza od 1600 m npm. i Gładkiego Upłaziańskiego od $1650 \mathrm{~m}$ npm. (Jahn, 1958) oraz formy sortowania mrozowego małej skali widoczne przy brzegach jezior, np. przy Czerwonym Stawku w Dolinie Pańszczycy na $1654 \mathrm{~m}$ npm. (Jahn, 1970b) (ryc. 2). Aktywne sortowane grunty strukturalne małej skali występują także wyżej, w rejonie Stawów Gąsienicowych (1800 m npm.) oraz na grzbiecie Czerwonych Wierchów (Jahn, 1950,

A

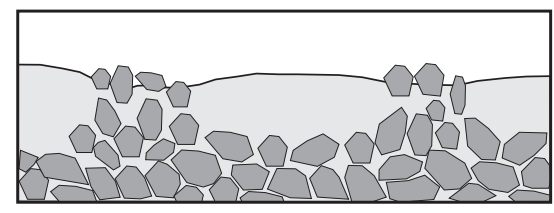

C

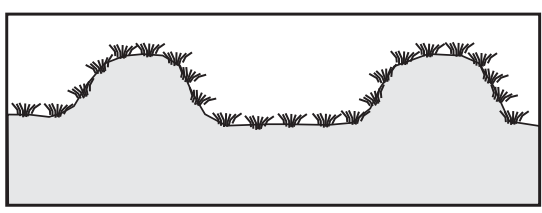

frakcja kamienista lub żwirowa coarse fraction

części ziemiste fine fraction
B

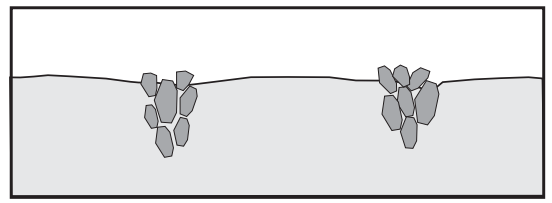

D

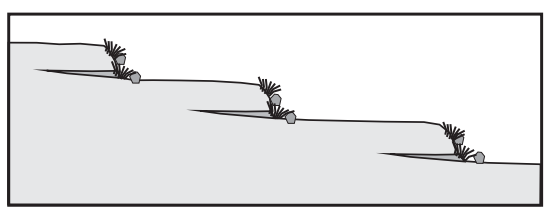

\begin{tabular}{|l}
\hline darner wer wer \\
turf
\end{tabular}

pogrzebany poziom próchniczny buried humic horizon

Ryc. 2. Schematyczne przekroje przez grunty strukturalne w alpejskiej strefie peryglacjalnej polskich gór: A - struktury sortowane o kamiennych granicach zakorzenionych w podścielających osadach gruboziarnistych (struktury małej lub dużej skali), B - struktury sortowane o gruboziarnistych granicach zawieszonych w drobnoziarnistym osadzie (zwykle struktury małej skali), C - tufury, D - terasetki, girlandy

Opracowanie własne na podstawie: Walczak (1948), Kunský i Záruba (1950), Sekyra (1956), Lukniš (1973).

Schematic cross-sections of patterned ground in the Polish alpine periglacial zone: A - sorted patterns of coarse domain anchored in underlying coarse-grained sediment (small or large scale patterns), B - sorted patterns of coarse domain suspended in fine-grained sediment (usually small-scale patterns), C - thufurs, D - terraces, garlands Author's elaboration based on: Walczak (1948), Kunský and Záruba (1950), Sekyra (1956), and Lukniš (1973). 
1951, 1970b). Na obszarach położonych ponad 2000 m npm. można zaobserwować poligony i sieci sortowane dużej skali, które mają charakter reliktowy - znane stanowisko na przełęczy Krzyżne na wysokości 2120 m npm. lub w okolicy Koszystej od 2040 m npm. (Jahn, 1950, 1951) (ryc. 2).

Mapy rozmieszczenia gruntów strukturalnych w Karkonoszach przedstawili m.in. W. Walczak (1948), J. Sekyra i Z. Sekyra (1995) oraz Křížek i inni (2007). Formy sortowania mrozowego występują tam głównie powyżej 1300 m npm.; jest to uwarunkowane wysokością wierzchowinowego poziomu zrównania, na którym istniały w plejstocenie dogodne warunki do rozwoju procesów mrozowych (Sekyra i Sekyra, 1995). Wieloletnia zmarzlina obecnie już nie występuje, lecz funkcjonowała tu przez całe zlodowacenie Wisły i prawdopodobnie aż do okresu 5000 BP (Jahn, 1977). W przypadku zarówno Karkonoszy jak i Tatr duże pierścienie, poligony czy pasy sortowane (o średnicy lub odstępie między pasami około $1 \mathrm{~m}$ i więcej) należy uważać przede wszystkim za relikt plejstoceński. Niemniej, w miejscach intensywnie przewiewanych, a tym samym o skąpej pokrywie śnieżnej, zamarzanie gruntu jest na tyle głębokie, że może powodować współczesną aktywność gruntów sortowanych dużej skali (Treml i inni, 2010). Tufury oraz małe sortowane pierścienie i sieci w wyjątkowo sprzyjających warunkach geoekologicznych współcześnie rozwijać się mogą nawet na wysokości 1245 m npm. - Śnieżne Stawki (Traczyk, 1992).

Aktywne sortowane grunty strukturalne spotykane w Tatrach i Karkonoszach są zwykle małej skali (średnica pierścieni lub poligonów $<1 \mathrm{~m}$ ) i związane ze zniszczeniem przez wiatr lub ludzi szaty roślinnej i działaniem lodu włóknistego na obnażonej powierzchni gruntu (Sekyra, 1954; Jahn, 1958; Pelíšek, 1974). W zagłębieniach terenu, gdzie formy sortowane występują najczęściej w strefach litoralnych płytkich jezior, głównym czynnikiem jest silne uwilgotnienie masy gruntowej (Lukniš, 1973; Traczyk, 1992). W takim położeniu występuje także zespół dużych (miejscami do 3,5 m średnicy) aktywnych poligonów sortowanych rozpoznanych przy Hińczowym Oku (w Tatrach słowackich) na wysokości 1948 m npm. przez M. Lukniša (1973) i Z. Rączkowską (2002, 2007). W. Dobiński (1997) dowiódł, że w Tatrach powyżej 1930 m npm. występują korzystne warunki do utrzymywania się wieloletniej zmarzliny. Wydaje się jednak, że współczesny rozwój aktywnych pierścieni, sieci czy poligonów nie wymaga permafrostu (Rączkowska, 2007), gdyż swoje powstanie zawdzięczają one głównie zróżnicowanemu pęcznieniu mrozowemu, a nie cyrkulacji en masse w obrębie warstwy czynnej (Washburn, 1973; Dąbski, 2006).

Formy sortowane małej skali mogą powstać bardzo szybko, w ciągu zaledwie kilku lat (Jahn, 1970b; Ballantyne, 1996), przy dużym udziale lodu włóknistego (Gerlach, 1959). W tej grupie form na szczególną uwagę zasługują sieci sortowane na powierzchni namuliska w tatrzańskiej Jaskini Czarnej, na 1340 m npm. (Pulina, 1968; Pulinowa i Pulina, 1972). Aktywne sortowanie mrozowe na tak małej wysokości (stanowisko ekstrazonalne) możliwe jest dzięki szczególnej cyr- 
kulacji powietrza w jaskini (strefa dynamiczna) oraz uwilgotnieniu drobnoziarnistego namuliska. O stosunkowo częstym występowaniu tego typu struktur w przywejściowych częściach jaskiń, głównie niewielkich schronów, w Niżnych Tatrach i w Wielkiej Fatrze na Słowacji (np. Jaskinia Jelenia) pisał P. Mitter (1983).

Duże pierścienie, sieci, poligony, stopnie (girlandy) czy pasy sortowane interpretowane są najczęściej jako struktury zachowane z epoki plejstoceńskiej (wyjątkiem są tu struktury przy Hińczowym Oku), które zachowały się dzięki położeniu na górskich grzbietach lub na wysokich przełęczach, gdzie erozja (szczególnie glacjalna w plejstocenie) była bardzo ograniczona. Zwietrzelina, w której wykształciły się te formy, została przepłukana przez wodę opadową i roztopową. Proces ten spowodował usunięcie (przemieszczanie w głąb gruntu) części ziemistych odpowiedzialnych za „wysadzinowość”, czyli podatność na pęcznienie mrozowe powierzchni gruntu (Beskow, 1935; Jahn, 1958, 1963). Miejscami stary, przepłukany poziom gruzowy (bruk peryglacjalny) pokryły płaty młodszej (holoceńskiej) zwietrzeliny rozwijającej się pod roślinnością trawiastą lub krzaczastą i tym samym na powierzchni gruntu uwidoczniają się „wiszące” płaty drobnoziarniste tworzące oczka sieci lub pierścieni sortowanych (Jahn, 1963). Stare sortowane grunty strukturalne dużej skali mogą do dziś zachowywać oznaki aktywności, a to w miejscach, gdzie nie do końca została usunięta ziemista zwietrzelina, w której tkwią wymarzające głazy (Jahn, 1963) oraz $\mathrm{w}$ miejscach silnie przewiewanych, w których procesy mrozowe sięgają szczególnie głęboko (Treml i inni, 2010).

W polskich Tatrach przykładem najlepiej wykształconych sortowanych gruntów strukturalnych dużej skali jest przełęcz Krzyżne (poligony i sieci o średnicy do $4 \mathrm{~m}$ ) na wysokości $2120 \mathrm{~m}$ npm. (Jahn, 1950, 1951), a w Tatrach słowackich Lučne sedlo (poligony i sieci o średnicy do $7 \mathrm{~m}$ ) na $2168 \mathrm{~m}$ npm. (Ksandr, 1954; Jahn, 1958; Lukniš, 1973). W Karkonoszach podobne struktury występują w wielu miejscach wzdłuż głównego zrównania wierzchowinowego (Treml i inni, 2010). Jedne z największych struktur odnotowano na Równi pod Śnieżką, gdzie maksymalna średnica poligonów wynosi do 4 m (Jahn, 1963; Sekyra i Sekyra, 1995).

Pojedyncze, słabo wykształcone zespoły sortowanych gruntów strukturalnych występują też w innych polskich masywach górskich. Można je spotkać powyżej górnej granicy lasu w Masywie Śnieżnika między 1380 a 1415 m npm. (Klementowski, 1995, 1998), na Babiej Górze na spłaszczeniu pod Diablakiem na około 1700 m npm. (Jahn, 1958) oraz na Krzemieńcu, Tarnicy i na Szerokim Wierchu w Bieszczadach powyżej 1250 m npm. (Pękala, 1969). Podobnie jak w przypadku Tatr i Karkonoszy, zarysy dużych poligonów sortowanych należy tu traktować jako relikty plejstoceńskie, natomiast sieci małej skali jako dowód na aktywność współczesnych procesów mrozowych. 


\section{Podsumowanie}

Kopalne grunty strukturalne, które można zaobserwować na zdjęciach lotniczych, występują w Polsce głównie w pasie nizin, najczęściej na Nizinie Wielkopolskiej. Formy reliktowe lub aktywne występują zaś ponad górną granicą lasu, głównie w tatrzańskim i karkonoskim piętrze alpejskim. Kopalne poligony mrozowe, czyli niesortowane grunty strukturalne dużej skali, będące świadectwem występowania wieloletniej zmarzliny w plejstocenie, możliwe są do sfotografowania tylko przy sprzyjających warunkach:

1) pogodowych - konieczny jest odpowiednio długi okres bez opadów na wiosnę umożliwiający zaistnienie wyraźnego kontrastu w uwilgotnieniu różnych utworów geologicznych (najczęściej glin zwałowych i piasków eolicznych);

2) roślinnych - najkorzystniejsza jest dojrzewająca uprawa jęczmienia, owsa lub lucerny;

3) względnie młodym wieku struktur mrozowych, objawiającym się brakiem znacznego przykrycia młodszymi osadami. Grunty strukturalne występują w polskich górach ponad górną granicą lasu, najczęściej w tatrzańskim i karkonoskim piętrze alpejskim, w formie sortowanej (sieci, pierścienie, poligony, stopnie lub pasy) lub niesortowanej (tufury). Sortowane grunty strukturalne dużej skali uważa się głównie za formy reliktowe ze schyłku plejstocenu, współcześnie możliwa jest jedynie ich częściowa aktywność przy sprzyjających warunkach geoekologicznych. Poligony sortowane przy Hińczowym Oku stanowią rzadki wyjątek współcześnie rozwijających się gruntów strukturalnych dużej skali. Formy małej skali rozwijają się w obecnych warunkach klimatycznych w piętrach alpejskich, a niekiedy, w wyjątkowo sprzyjającej sytuacji geoekologicznej, także w niższych partiach.

Autor serdecznie dziękuje prof. Włodzimierzowi Rączkowskiemu z Instytutu Prahistorii UAM oraz dr. Dariuszowi Krasnodębskiemu z Instytutu Archeologii i Etnologii PAN za udostępnienie zdjęć.

\section{Piśmiennictwo}

Andusov D., 1954, Polygonálne pôdy na dne tatranských plies, Geologický Zborník, 5, s. $107-110$.

Ballantyne C.K., 1996, Formation of miniature sorted patterns by shallow ground freezing: a field experiment, Permafrost and Periglacial Processes, 7, s. 409-424.

Ballantyne C.K., Harris C., 1994, The Periglaciation of Great Britain, Cambridge University Press, Cambridge. 
Beskow G., 1935, Tjälbildningen och tjällyftningen með särskild hänsyn till vägar och järnvägar, Sveriges Geologiska Undersökning, 26, 3.

Bogdański P., Kijowski A., 1990, Photointerpretation of geometry of Vistulian ice-wedge polygons: the Grabianowo and the Sulejewo sites, south of Poznan, Quaestiones Geographicae, 11/12, s. 39-52.

Champion S., 1980, A Dictionary of Terms and Techniques in Archeology, Phaidon, Oxford.

Christensen L., 1974, Crop-marks revealing large-scale patterned ground structures in cultivated areas, southwestern Jutland, Denmark, Boreas, 3, s. 153-180.

Dąbski M., 2006, Geneza sortowanych gruntów strukturalnych - przegląd literatury, Przegląd Geograficzny, 78, 1, s. 91-107.

Dąbski M., Łapaj K., Pudłowski M., 2007, Identyfikacja poligonów mrozowych na podstawie analizy zdjęć lotniczych z rejonu Kruszwicy, [w:] E. Smolska, D. Giriat (red.), Rekonstrukcja dynamiki procesów geomorfologicznych - formy rzeźby i osady, Wydział Geografii i Studiów Regionalnych UW, Komitet Badań Czwartorzędu PAN, Warszawa, s. 117-123.

-, 2008, Fotografia lotnicza jako narzędzie do identyfikacji kopalnych poligonów mrozowych, Zeszyty Naukowe Szkoły Wyższej Przymierza Rodzin w Warszawie, Seria geograficzno-turystyczna, 1, s. 59-66.

Dąbski M., Szwajgier W., 2005, Struktury peryglacjalne w osadach terasy vistuliańskiej doliny Bugu w Obniżeniu Dubienki, Annales UMCS, 60, 6, s. 85-94.

Dobiński W., 1997, Distribution in mountain permafrost in the High Tatra Mts., based on freezing and thawing indices, Biuletyn Peryglacjalny, 36, s. 29-45.

Emblelon C., King C.A.M., 1975, Periglacial Geomorphology, Arnold, London.

van Everdingen R.O., 1998, Multi-Language Glossary of Permafrost and Related Groung-Ice Terms, International Permafrost Association, Calgary.

French H.M., 1996, The Periglacial Environment, Longman, Singapore.

Gawlik H., 1970, Wieloboki peryglacjalnych szczelin mrozowych na obszarze Polski środkowej w świetle interpretacji zdjęć lotniczych, Fotointerpretacja w Geografii, 8, s. $71-80$.

Gerlach T., 1959, Lód wtóknisty i jego rola w przemieszczaniu pokrywy zwietrzelinowej w Tatrach, Przegląd Geograficzny, 31, 2, s. 589-605.

-, 1970, État actuel et methods de recherches sur les processus morphogénétiques actueles sur le fond des étages climatiques et végétaux dans les Carpates Polonaises, Studia Geomorphologica Carpatho-Balcanica, 4, s. 45-63.

Goździk J., 1973, Geneza i pozycja stratygraficzna struktur peryglacjalnych w środkowej Polsce, Acta Geographica Lodziensia, 31.

Jahn A., 1950, Gleby strukturalne w polskiej części Tatr, Przegląd Geograficzny, 22, s. 121-139.

-, 1958, Mikrorelief peryglacjalny Tatr i Babiej Góry, Biuletyn Peryglacjalny, 6, s. 57-80.

-, 1963, Gleby strukturalne Czarnego Grzbietu i problem utworów pylastych w Karkonoszach, Acta Universitatis Wratislaviensis, Studia Geograficzne, I, 9, s. 55-65.

-, 1970a, Zagadnienia strefy peryglacjalnej, PWN, Warszawa.

-, 1970b, Najniższe stanowisko czynnych gruntów strukturalnych w Tatrach i problem dolnej granicy występowania zjawisk peryglacjalnych w górach, Acta Geographica Lodziensia, 24, s. 217-224.

-, 1977, The permafrost active layer in the Sudety mountains during the last glaciation, Quaestiones Geographicae, 4, s. 29-42.

Johnson W.H., 1990, Ice-wedge cast and relict patterned ground in Central Illinois and their environmental significance, Quaternary Research, 33, s. 51-72. 
Kessler M.A., Werner B.T., 2003, Self-organization of sorted patterned ground, Science, 299, s. 380-383.

Kijowski A., Żynda S., 2005, Struktury glacjalne i peryglacjalne jako tło dla archeologicznej interpretacji zdjęć lotniczych, [w:] J. Nowakowski, A. Prinke, W. Rączkowski (red.), Biskupin... i co dalej?, Instytut Prahistorii UAM, Ośrodek Ochrony Dziedzictwa Archeologicznego, Muzeum Archeologiczne w Biskupinie, Poznańskie Towarzystwo Prehistoryczne, Poznań, s. 145-156.

Klementowski J., 1995, Wspótczesne grunty strukturalne Sudetów w świetle kriogenicznych ruchów ich powierzchni, [w:] T. Szczypek (red.), III Zjazd Geomorfologów Polskich - „Procesy Geomorfologiczne, zapis w rzeźbie i osadach”, Stowarzyszenie Geomorfologów Polskich, Sosnowiec, s. 36-37.

-, 1998, Nowe stanowisko gruntów strukturalnych na Śnieżniku, Czasopismo Geograficzne, 69, 1, s. 73-85.

Kotarba A., Starkel L., 1972, Holocene morphogenetic altitudinal zones in the Carpathians, Studia Geomorphologica Carpatho-Balcanica, 6, s. 21-35.

Kozarski S., 1993, Late Plenivistulian deglaciation and the expansion of the periglacial zone in NW Poland, Geologie en Mijnbouw, 72, s. 143-157.

-, 1995, Deglacjacja pótnocno-zachodniej Polski: warunki środowiska i transformacja geosystemu (20 KA-10 KA BP), Dokumentacja Geograficzna, 1, IGiPZ PAN, Warszawa.

Křížek M., Treml V., Engel Z., 2007, Zákonitosti prostorového rozmístěni periglaciálních tvarů v Krkonoaich nad alpinskou hranicí lesa, Opera Corcontica, 44, 1, s. 67-80.

Ksandr L., 1954, Mrazové půdni formy v Tatrách (Frost soil forms in the Tatra), Ochrana Přirody, 9.

Kunský J., Louček D., 1956, Stone stripes and thufurs in the Krkonoše, Biuletyn Peryglacjalny, 4, s. 345-349.

Kunský J., Záruba Q., 1950, Periglaciálni strukturní půdy v Krkonoších, Sbornik Československé Společnosti Zemépisné, 55, 1-2, s. 10-14.

Lukniš M., 1973, Reliéf Vysokých Tatier a ich predpolia, Vydavatel'stvo Slovenskej akadémie vied, Bratislava.

Maizels J., 1986, Frequency of relict frost-fissure structures and prediction of polygon pattern, a quantitative approach, Biuletyn Peryglacjalny, 30, s. 67-89.

Mitter P., 1983, Frost features in the kart regions of the West Carpathian mountains, [w:] IV International Conference on Permafrost, Fairbanks, National Academy Press, Washington, s. 861-865.

Morgan A.V., 1971, Polygonal patterned ground of Late Weichcelian age in the area North and West of Wolverhampton, England, Geografiska Annaler, 53 A, 3-4, s. 146-156.

Pelíšek J., 1974, Půdy Krkonošského Národního Parku, Opera Corcontica, 11, s. 7-35.

Pękala K., 1969, Rumowiska skalne i wspótczesne procesy morfogenetyczne $w$ Bieszczadach Zachodnich, Annales UMCS, 24, 2, s. 47-81.

Popov A.I., 1962, Pokrovnyje suglinki $i$ poligonalnyj relief Bolseziemielskoj tundry, [w:] A.I. Popov (red.), Voprosy geograficeskogo merzlotovedienia i periglacjalnoj morfologii, Izdatielstvo Mockovskogo Universiteta, Moskva, s. 109-130.

Pulina M., 1968, Gleby poligonalne w Jaskini Czarnej (Tatry Zachodnie), Speleologia, 3, 2, s. 99-102.

Pulinowa M.Z., Pulina M., 1972, Phénomènes cryogènes dans les grottes et gouffres des Tatras, Biuletyn Peryglacjalny, 21, s. 201-235.

Rączkowska Z., 2002, Stanowisko czynnych gruntów strukturalnych przy Hińczowym Stawie, Tatry Stowackie, [w:] Materiaty konferencyjne. VI Zjazd Geomorfologów Polskich - „Środowisko górskie - ewolucja rzeźby”, Jelenia Góra 11-14 września 2002, Instytut Geograficzny, Uniwersytet Wrocławski, Wrocław, s. 109-110. 
-, 2007, Wspótczesna rzeźba peryglacjalna wysokich gór Europy, Prace Geograficzne, IGiPZ PAN, 212, Warszawa.

Sekyra J., 1950, Thufury a guirlandové půdy v Bělských Tatrách, Sbornik Československé Společnosti Zemepisné, 55, 3-4, s. 214-219.

-, 1954, K otázce recentnosti strukturních půd (Z kryopedologického výzkumu v oblasti Velká Kopa 2035 m - Križné 2040 m ve Vysokých Tatrách), Vestník Ústředního ústavu geologického, 31, s. 21-32.

-, 1956, The development of cryopedology in Czechoslovakia, Biuletyn Peryglacjalny, 4, s. 351-369.

Sekyra J., Sekyra Z., 1995, Recent cryogenic processes, [w:] L. Soukupová, M. Kociánová, J. Jeník, J. Sekyra (red.), Arctic-alpine Tundra in the Krkonoše, the Sudetes, Opera Corcontica, 32, s. 5-88.

Shotton F.W., 1960, Large scale patterned ground in the valley of the Worcestershire Avon, Geological Magazine, 97, s. 404-408.

Svensson H., 1964, Aerial photographs for tracing and investigating fossil tundra ground in Scandinavia, Biuletyn Peryglacjalny, 14, s. 321-325.

-, 1982, The use of aerial photographs and remote sensing techniques in research on fossil periglacial features, Biuletyn Peryglacjalny, 29, s. 129-138.

Traczyk A., 1992, Formy wspótczesnego sortowania mrozowego w Karkonoszach i klimatyczne uwarunkowanie ich rozwoju, Czasopismo Geograficzne, 63, 3-4, s. 351-359.

Tokaj A., 2011, Poligony mrozowe w okolicach Otorowa (Pojezierze Poznańskie), Wydział Geografii i Studiów Regionalnych UW, Warszawa, maszynopis.

Treml V., Krizek, M., Engel Z., 2010, Classification of patterned ground based on morphometry and site characteristics: a case study from the High Sudetes, Central Europe, Permafrost and Periglacial Processes, 21, s. 67-77.

Walczak W., 1948, Gleby strukturalne w Karkonoszach, Przegląd Geograficzny, 21, 3-4, s. 227-241.

Walters J.C., 1978, Polygonal patterned ground in Central New Jersey, Quaternary Research, 10, s. 42-54.

-, 1994, Ice-Wedge Cast and Relict Polygonal Patterned Ground in the North-East Iowa, USA, Permafrost and Periglacial Processes, 5, s. 269-282.

Washburn A.L., 1956, Classification of patterned ground and review of suggested origins, Geological Society of America Bulletin, 67, s. 823-865.

-, 1970, An approach to a genetic classification of patterned ground, Acta Geographica Lodzensia, 24, s. 437-446.

-, 1973, Periglacial Processes and Environments, Arnold, London.

-, 1979, Geocryology: A Survey of Periglacial Processes and Environments, Arnold, London.

Widacki W., 1975, Mrozowe ruchy gruntu w Polsce Potudniowej (Frost-induced ground movements in south Poland - summary), Zeszyty Naukowe Uniwersytetu Jagiellońskiego, Prace Geograficzne, 41, 63, s. 139-197.

Williams R.B.G., 1964, Fossil patterned ground in eastern England, Biuletyn Peryglacjalny, 14, s. 337-349.

Zatko M., 1961, Príspevok ku geomorfológii Furkotskej, Suchej a Važeckej doliny v západnej časti Vysokých Tatier, Geografický Časopis, 13, s. 271-295.

[Wpłynęło: październik 2010; poprawiono: luty 2011 r.] 


\section{MACIEJ DĄBSKI}

\section{PATTERNED GROUNDS IN POLAND}

The article addresses the issue of patterned grounds in Poland, understood as regular, ordered patterns contemporarily visible on the ground surface. The described structures can be divided into those occurring on (mainly lowland) terrain occupied during the Pleistocene by continental glaciations, and those occurring in the alpine periglacial zone of the Polish Carpathians and Sudetes (and mainly in the Tatra and Karkonosze ranges).

The non-montane patterned grounds are fossil large-scale non-sorted polygons and can be observed only on aerial pictures (Plates 1 and 2), and then only when conditions are suitable in respect of the weather, lithology and land use. Thus the identification of fossil frost polygons is facilitated by at least two weeks with little precipitation, significant differences in texture between host sediments and frost-fissure infill, a relatively young age of the polygons and the superficial occurrence of frost wedges (with relatively thin overlying sediments), and proper land use - preferably ripening barley, oats or alfalfa. Notwithstanding these rather exacting conditions, fossil large-scale non-sorted frost polygons have proved detectable in numerous aerial pictures taken in the youngglacial landscape of the Wielkopolska region (near Poznań), but also in the old-glacial landscape of central and eastern Poland. The polygons testify to the existence of permafrost conditions during the last glacial period.

Near Dubienka in SE Poland there is a system of dry valleys (2-4 m deep and 10-20 $\mathrm{m}$ wide) which developed on the Wartanian (Riss) river terrace in a quasi-polygonal pattern. The landforms here resemble those found on the Laholm Plain (SW Sweden), as well as blocky relief in Siberia (Fig. 1), and they are thought to originate out of thermokarstic subsidence on former large scale ice-wedges.

The alpine periglacial zone of the Polish mountains is found most of all in the Tatra and Karkonosze Mountains, in their alpine and subalpine zones. Patterned ground includes thufurs, sorted patterns (circles, polygons, nets and stripes) and garlands (Fig. 2). In the Tatras, active thufurs have been reported from the slopes of Kominy Tylkowe (from 1500 m a.s.l.), Mała Koszysta (from 1600 m), Kobylarz (from 1600 m) and Gładkie Upłaziańskie (from $1650 \mathrm{~m}$ a.s.l.). Active small-scale sorted nets and circles occur near lake shorelines, e.g. Czerwony Stawek in the Pańszczyca Valley $1654 \mathrm{~m}$ a.s.l., and at higher altitudes - e.g. at Stawy Gąsienicowe $(1800 \mathrm{~m})$ or on the Czerwone Wierchy (about $2000 \mathrm{~m}$ a.s.l.). Small-scale sorted nets can develop even today at such extrazonal locations as the floor of the Jaskinia Czarna cave at $1340 \mathrm{~m}$ a.s.l. Large-scale sorted polygons and nets can be found in elevated places which were not subject to glacial erosion or mass-wasting. Best known locations are: the Krzyżne pass $(2120 \mathrm{~m}$ a.s.l.), with polygons up to $4 \mathrm{~m}$ in diameter, and parts of the Koszysta Ridge (above 2040 $\mathrm{m}$ a.s.l.). Large-scale sorted patterns are mostly relict, despite contemporary permafrost occurrence above $1930 \mathrm{~m}$ a.s.l.

In the Karkonosze Mountains, sorted patterned ground usually occurs above $1300 \mathrm{~m}$ a.s.l. and is associated with the planation level of the main ridge, as was predisposed to frequent ground freezing and thawing during the Pleistocene. One of the best known sites of large sorted polygons (up to $4 \mathrm{~m}$ in diameter) is Równia pod Śnieżką. Permafrost 
in the Karkonosze had probably thawed by 5000 yr. BP, hence the large-scale sorted patterns are relict. However, in places exposed to intensive deflation, deep ground freezing may reactivate some of the large-scale sorted patterns. Given favorable geoecological conditions, thufurs and small-scale nets and circles can develop contemporarily in places located at relatively low altitude (e.g. Śnieżne Stawki at $1245 \mathrm{~m}$ a.s.l.).

Poorly-developed sorted patterned grounds can also be found in other Polish mountains above the treeline, e.g. on the Śnieżnik Massif and Babia Góra, as well as on Krzemieniec, Tarnica, and Szeroki Wierch in the Bieszczady Mountains. 
http://rcin.org.pl 